\title{
Profil Klinikopatologik Biopsi Massa Kolorektal di Instalasi Patologi Anatomi RSUD Arifin Achmad Provinsi Riau Periode Januari 2015 - Desember 2019
}

\author{
Ilhami Romus*1, Khairun Nisa'2
}

\begin{abstract}
Colorectal masses can be non-neoplasm, benign neoplasm and malignant neoplasm. Diagnosis of colorectal mass can be done by biopsy or surgery then followed by histopathological examination. The aim of this study was to described the histopathology feature of colorectal mass biopsy in the Anatomic Pathology Laboratory of Arifin Achmad Regional Hospital in Riau Province January 2015 - December 2019. This study found 304 cases consisted of men (55,6\%) and women $(44,4 \%)$. The highest number of cases was in the $50-59$ years age group $(29,3 \%)$. The Malays $(17,8 \%)$ was the largest ethnic group. The highest occupation was housewives $(22 \%)$. Rectal tumor $(73,1 \%)$ was the most common clinical diagnosis. The histopathological examination results of colorectal mass biopsy were non-neoplasm (26,7\%), benign neoplasm (1,3\%), and malignant neoplasm (72\%). Adenocarcinoma was the most common biopsy histopathologic feature of malignant neoplasm $(64,8 \%)$.
\end{abstract}

Keywords : Colorectal Mass, Colorectal Biopsy, Histopathology

Kolon dan rektum merupakan bagian dari sistem pencernaan yaitu usus besar yang merupakan saluran pencernaan bagian terakhir. Bakteri yang terdapat di dalam kolon dan rektum memiliki jumlah sepuluh kali lipat lebih banyak dibandingkan dengan sel eukariotik di tubuh manusia. Jumlah bakteri yang banyak tersebut sering kali menyebabkan proses inflamasi dan infeksi pada kolon sehingga tidak mengherankan apabila kolon adalah tempat tersering dari neoplasma saluran cerna pada populasi negara Barat. ${ }^{1}$

World Health Organization (WHO) pada tahun 2000 telah mengklasifikasikan histopatologi tumor pada kolon dan rektum menjadi 35 nama jenis tumor yang terbagi menjadi tumor epitelial, tumor non-epitelial, tumor sekunder, dan polip. ${ }^{2}$ Adenokarsinoma merupakan salah satu jenis keganasan pada kolon dan rektum yang paling sering terjadi pada saluran cerna dan merupakan

\footnotetext{
* Corresponding author: ilhamiromus@yahoo.co.id

1 KJFD Patologi Anatomi Fakultas Kedokteran Universitas Riau, Pekanbaru, Riau, Indonesia

2 Program Studi Kedokteran Fakultas Kedokteran Universitas Riau Pekanbaru, Riau, Indonesia
}

kontributor utama dari morbiditas dan mortalitas di dunia. ${ }^{1}$

American Cancer Society melaporkan bahwa neoplasma ganas yaitu kanker kolorektal merupakan kanker ketiga terbanyak dan kanker penyebab kematian ketiga terbanyak di Amerika Serikat untuk pria dan wanita. ${ }^{3}$ Survei GLOBOCAN pada tahun 2012 melaporkan bahwa insiden kanker kolorektal di Indonesia adalah 12,8 per 100.000 penduduk usia dewasa, dengan mortalitas 9,5\% dari seluruh kasus kanker. ${ }^{4}$ Penelitian Hamdi dkk, pada tahun 2015 di bagian Laboratorium Patologi Anatomi Fakultas Kedokteran Universitas Andalas yang mengumpulkan data dari bulan Januari 2009 sampai Desember 2011 tercatat 260 penderita karsinoma kolorektal dengan jenis histopatologi terbanyak yaitu adenokarsinoma. ${ }^{5}$ Sementara data mengenai prevalensi massa kolorektal belum diketahui secara pasti.

Penegakan diagnosis massa kolorektal dapat dilakukan secara bertahap, antara lain melalui anamnesis yang tepat, pemeriksaan fisik dan pemeriksaan penunjang berupa pemeriksaan 
laboratorium sederhana, kemudian pemeriksaan penunjang berikutnya berupa pencitraan seperti foto polos atau dengan kontras (barium enema), kolonoskopi, CT Scan, MRI, dan Ttransrectal Ultrasound. Kolonoskopi merupakan modalitas pemeriksaan awal yang paling memadai diantara pemeriksaan penunjang lainnya karena memiliki sensitivitas $95 \%$ untuk polip dan adenokarsinoma kolorektal dan tanpa adanya paparan radiasi. Biopsi dapat langsung dilakukan untuk menegakkan diagnosis massa kolorektal secara cepat pada saat dilakukan kolonoskopi. Akurasi yang tinggi disertai dengan uji diagnostik yang cepat akan sangat berperan dalam penatalaksanaan yang lebih cepat dan tepat. Sampel biopsi yang telah didapatkan dari dokter ahli bedah digestif dan dokter Konsultan Gastroenterologi kemudian akan dilakukan pemeriksaan histopatologi oleh Dokter Spesialis Patologi Anatomi untuk menilai ada tidaknya keganasan, jenis tumor, infeksi yang bersifat akut atau kronik, dan berbagai kelainan lainnya. Faktor yang mempengaruhi pemeriksaan histopatologi biopsi adalah kemampuan patolog dan keterampilan klinisi untuk mengambil sampel yang representatif. ${ }^{6-8}$ Penelitian ini bertujuan untuk melihat gambaran klinikopatologik biopsi massa kolorektal di instalasi Patologi Anatomi RSUD Arifin Achmad provinsi Riau periode Januari 2015 - Desember 2019.

\section{METODE}

Penelitian ini bersifat deskriptif dengan mengumpulkan data sekunder dari arsip di Instalasi Patologi Anatomi dan Instalasi Rekam Medis. Populasi pada penelitian ini adalah seluruh data arsip penderita yang dilakukan pemeriksaan histopatologi biopsi massa kolorektal di Instalasi Patologi Anatomi dan Instalasi Rekam Medis RSUD Arifin Achmad Provinsi Riau periode Januari 2015 - Desember 2019. Seluruh populasi pada penelitian ini menjadi sampel penelitian (total sampling). Selanjutnya data yang diperoleh dikelompokkan berdasarkan variabel penelitian dan disajikan dalam bentuk tabel distribusi frekuensi, presentase dan narasi untuk digunakan dalam penarikan kesimpulan. Penelitian telah mendapatkan persetujuan etik dari Unit Etika Penelitian Kedokteran dan Kesehatan Fakultas Kedokteran Universitas Riau, Nomor: B/143/ UN19.5.1.1.8/UEPKK/2020.

\section{HASIL}

Pasien yang dilakukan pemeriksaan histopatologi biopsi massa kolorektal di Instalasi Patologi Anatomi RSUD Arifin Achmad Provinsi Riau Periode Januari 2015 - Desember 2019 berjumlah 304 orang. Umur terendah pasien adalah 3 tahun dan umur tertinggi 82 tahun dengan rerata umur pasien adalah 51 tahun.

\section{Karaktertistik Pasien yang Dilakukan Pemeriksaan Histopatologi Biopsi Massa Kolorektal}

Karakteristik pasien berdasarkan umur, jenis kelamin, suku, dan pekerjaan dapat dilihat pada tabel 1.

Tabel 1 Distribusi Frekuensi Karakteristik Pasien yang Dilakukan Pemeriksaan Histopatologi Biopsi Massa Kolorektal

\begin{tabular}{|c|c|c|c|}
\hline \multicolumn{2}{|c|}{ Karakteristik Pasien } & Frekuensi (n) & $\begin{array}{c}\text { Presentase } \\
(\%)\end{array}$ \\
\hline \multicolumn{4}{|c|}{ Jenis Kelamin } \\
\hline & Laki-laki & 169 & 55,6 \\
\hline$\bullet$ & Perempuan & 135 & 44,4 \\
\hline \multicolumn{2}{|l|}{ Total } & 304 & 100 \\
\hline \multicolumn{4}{|l|}{ Umur } \\
\hline$\bullet$ & $<40$ tahun & 62 & 20,4 \\
\hline$\bullet$ & 40 - 49 tahun & 66 & 21,7 \\
\hline$\bullet$ & $50-59$ tahun & 89 & 29,3 \\
\hline$\bullet$ & $60-70$ tahun & 67 & 22,0 \\
\hline$\bullet$ & $>70$ tahun & 20 & 6,6 \\
\hline \multicolumn{2}{|l|}{ Total } & 304 & 100 \\
\hline \multicolumn{4}{|l|}{ Suku } \\
\hline & Melayu & 54 & 17,8 \\
\hline$\bullet$ & Jawa & 43 & 14 \\
\hline & Batak & 23 & 7,6 \\
\hline & Minang & 23 & 7,6 \\
\hline & Tionghoa & 2 & 0,7 \\
\hline & Bugis & 4 & 1,3 \\
\hline & Banjar & 3 & 1 \\
\hline$\bullet$ & Tidak ada data & 152 & 50 \\
\hline \multicolumn{2}{|c|}{ Total } & 304 & 100 \\
\hline \multicolumn{4}{|c|}{ Pekerjaan } \\
\hline & Petani & 30 & 9,9 \\
\hline & $\begin{array}{l}\text { P e g a w a i } \\
\text { Negeri Sipil }\end{array}$ & 17 & 5,6 \\
\hline • & Karyawan & 31 & 10,2 \\
\hline$\bullet$ & Wiraswasta & 32 & 10,5 \\
\hline$\bullet$ & Pensiun & 7 & 2,3 \\
\hline & $\begin{array}{l}\text { Ibu Rumah } \\
\text { Tangga }\end{array}$ & 67 & 22 \\
\hline & Pelajar & 1 & 0,3 \\
\hline & Tidak bekerja & 12 & 4 \\
\hline$\bullet$ & Tidak ada data & 107 & 35,2 \\
\hline Total & & 304 & 100 \\
\hline
\end{tabular}


Tabel 1 menggambarkan bahwa pasien yang dilakukan pemeriksaan histopatologi biopsi massa kolorektal paling banyak ditemukan berjenis kelamin laki-laki yaitu sebanyak 169 orang $(55,6 \%)$. Karakteristik pasien berdasarkan umur menunjukkan hasil bahwa kelompok umur terbanyak pada sampel penelitian ini adalah kelompok umur 50 - 59 tahun sebanyak 89 orang $(29,3 \%)$ dan yang paling sedikit ditemukan pada kelompok umur $>70$ tahun sebanyak 20 orang $(6,6 \%)$. Sementara karakteristik suku dan pekerjaan terbanyak ditempati oleh suku Melayu sebanyak 54 orang $(17,8 \%)$ dan pekerjaan Ibu Rumah Tangga sebanyak 67 orang (22\%).

\section{Diagnosis Klinik Pasien yang Dilakukan Pemeriksaan Histopatologi Biopsi Massa Kolorektal}

Diagnosis klinik pasien yang dilakukan pemeriksaan histopatologi biopsi massa kolorektal pada penelitian ini dapat dilihat pada tabel 2 .

Tabel 2 Distribusi Frekuensi Diagnosis Klinik Pasien yang Dilakukan Pemeriksaan Histopatologi Biopsi Massa Kolorektal

\begin{tabular}{lcc}
\hline Diagnosis klinik & $\begin{array}{c}\text { Frekuensi } \\
(\mathbf{n})\end{array}$ & $\begin{array}{c}\text { Presentase } \\
(\mathbf{\%})\end{array}$ \\
\hline Tumor sekum & 14 & 4,6 \\
Tumor kolon asendens & 9 & 3 \\
Tumor kolon transversum & 5 & 1,6 \\
Tumor kolon desendens & 4 & 1,3 \\
Tumor kolon sigmoid & 14 & 4,6 \\
Tumor rektosigmoid & 8 & 2,6 \\
Tumor rektum & 222 & 73,1 \\
Tumor anorektal & 21 & 6,9 \\
Polip & 7 & 2,3 \\
\hline Total & $\mathbf{3 0 4}$ & $\mathbf{1 0 0}$ \\
\hline
\end{tabular}

Tabel 2 menunjukkan bahwa hasil diagnosis klinik yang terbanyak adalah tumor rektum yaitu sebanyak 222 kasus $(73,1 \%)$ dan yang paling sedikit adalah tumor kolon desendens yaitu sebanyak 4 kasus (1,3\%).

\section{Gambaran Histopatologi Biopsi Massa Kolorektal}

Gambaran histopatologi biopsi massa kolorektal di RSUD Arifin Achmad Provinsi Riau tahun 2015 2019 dapat dilihat pada tabel 3 di bawah ini.
Tabel 3 Distribusi Frekuensi Gambaran Histopatologi Biopsi Massa Kolorektal di RSUD Arifin Achmad Provinsi Riau Tahun 2015 - 2019

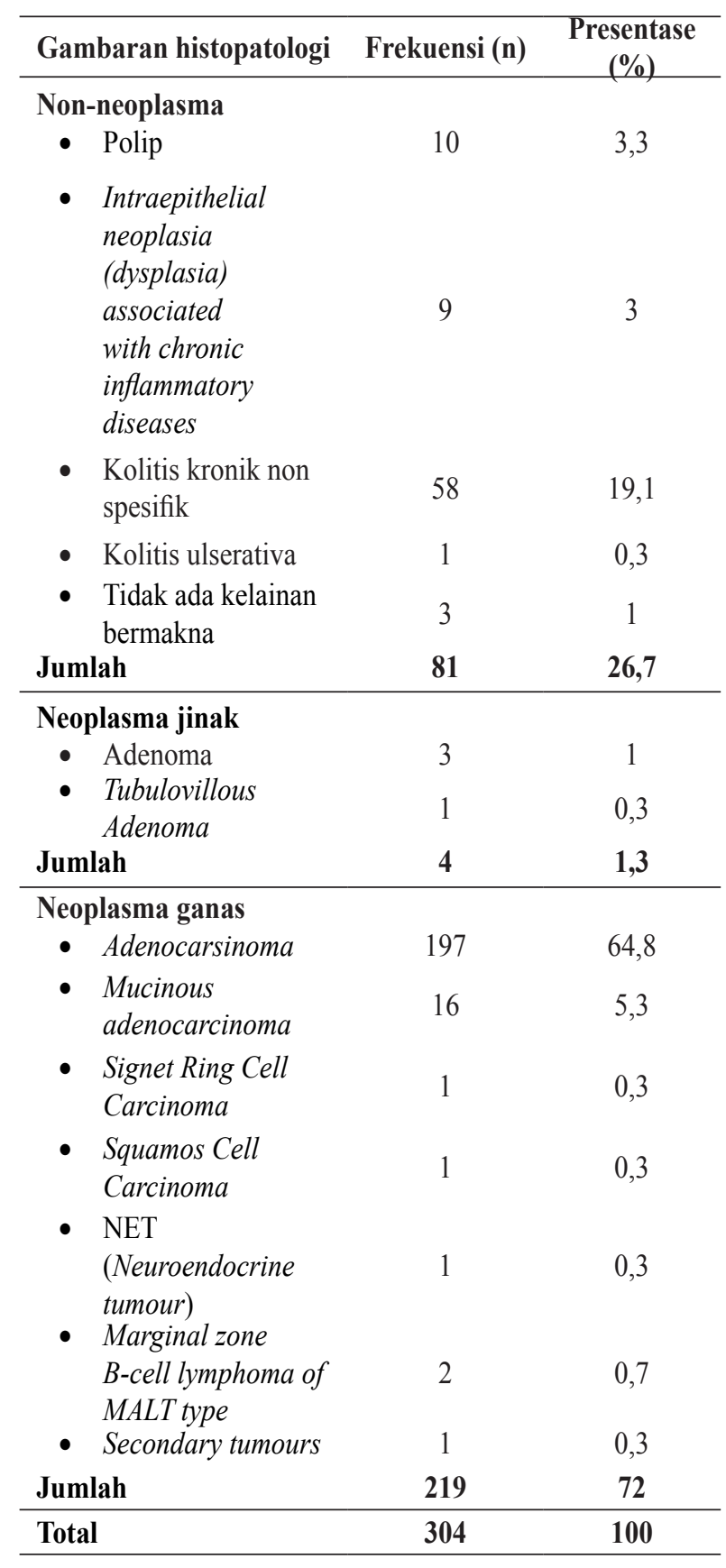

Tabel 3 menunjukkan bahwa gambaran hasil pemeriksaan histopatologi biopsi massa kolorektal yang paling banyak ditemukan adalah neoplasma ganas yang mendominasi proporsi kasus sebanyak 219 spesimen (72\%), diikuti dengan gambaran histopatologi non-neoplasma sebanyak 81 spesimen 
(26,7\%), dan neoplasma jinak sebanyak 4 spesimen $(1,3 \%)$. Hasil penelitian ini juga menunjukkan bahwa dari seluruh hasil pemeriksaan histopatologi biopsi massa kolorektal non-neoplasma yang paling banyak yaitu kolitis kronik non spesifik sebanyak 58 spesimen $(19,1 \%)$, neoplasma jinak yaitu adenoma sebanyak 3 spesimen (1\%), dan neoplasma ganas yaitu adenokarsinoma sebanyak 197 spesimen $(64,8 \%)$.

\section{Gambaran Histopatologi Biopsi Massa Kolorektal Berdasarkan Diagnosis Klinik}

Gambaran histopatologi biopsi massa kolorektal berdasarkan diagnosis klinik pada pasien yang dilakukan pemeriksaan histopatologi biopsi massa kolorektal dapat dilihat pada tabel 4.

Tabel 4 Distribusi Frekuensi Gambaran Histopatologi Biopsi Massa Kolorektal Berdasarkan Diagnosis Klinik pada Pasien yang Dilakukan Pemeriksaan Histopatologi Biopsi Massa Kolorektal

\begin{tabular}{lcccccc}
\hline & \multicolumn{5}{c}{ Gambaran histopatologi } \\
\cline { 2 - 7 } \multicolumn{1}{c}{ Diagnosis klinik } & \multicolumn{2}{c}{ Non-neoplasma } & \multicolumn{2}{c}{ Neoplasma jinak } & \multicolumn{2}{c}{ Neoplasma ganas } \\
\cline { 2 - 7 } & $\mathrm{N}$ & $\%$ & $\mathrm{~N}$ & $\%$ & $\mathrm{~N}$ & $\%$ \\
\hline Tumor sekum & 9 & 3 & 0 & 0 & 5 & 1,6 \\
Tumor kolon asendens & 4 & 1,3 & 0 & 0 & 5 & 1,6 \\
Tumor kolon transversum & 1 & 0,3 & 0 & 0 & 4 & 1,3 \\
Tumor kolon desendens & 1 & 0,3 & 1 & 0,3 & 2 & 0,7 \\
Tumor kolon sigmoid & 5 & 1,6 & 0 & 0 & 9 & 3 \\
Tumor rektosigmoid & 1 & 0,3 & 0 & 0 & 7 & 2,3 \\
Tumor rektum & 51 & 16,9 & 3 & 1 & 168 & 55,2 \\
Tumor anorektal & 3 & 1 & 0 & 0 & 18 & 6 \\
Polip & 6 & 2 & 0 & 0 & 1 & 0,3 \\
\hline
\end{tabular}

Tabel 4 menggambarkan bahwa tumor rektum merupakan diagnosis klinik yang paling banyak ditemukan dengan gambaran histopatologi non-neoplasma sebanyak 51 orang $(16,9 \%)$, neoplasma jinak sebanyak 3 orang $(1 \%)$ dan neoplasma ganas sebanyak 168 orang $(55,2 \%)$. Sementara itu, tumor kolon desendens merupakan diagnosis klinik yang paling sedikit ditemukan dengan gambaran histopatologi non-neoplasma sebanyak 1 orang $(0,3 \%)$, neoplasma jinak sebanyak 1 orang $(0,3 \%)$, dan neoplasma ganas sebanyak 2 orang $(0,7 \%)$.

\section{PEMBAHASAN}

\section{Karaktertistik Pasien yang Dilakukan Pemeriksaan Histopatologi Biopsi Massa Kolorektal}

Hasil penelitian ini menunjukkan bahwa pasien yang dilakukan pemeriksaan histopatologi biopsi massa kolorektal paling banyak berjenis kelamin laki-laki yaitu sebanyak 169 orang $(55,6 \%)$. Hasil ini sama dengan penelitian Devi dkk di RSUP Sanglah Denpasar pada tahun
2015-2017 yang menemukan proporsi pasien yang dilakukan pemeriksaan histopatologi biopsi massa kolorektal berdasarkan jenis kelamin yang tertinggi adalah laki-laki sebanyak 171 orang $(55,5 \%){ }^{9}$ Hasil penelitian ini juga sejalan dengan penelitian Fuadi dkk di RSCM pada tahun 2006 - 2015 yang menemukan proporsi pasien yang dilakukan pemeriksaan histopatologi biopsi massa kolorektal berdasarkan jenis kelamin yang tertinggi adalah laki-laki sebanyak 28 orang $(58,3 \%) .{ }^{10}$ Jenis kelamin laki-laki lebih berisiko untuk terkena kanker kolorektal diandingkan dengan perempuan diakibatkan oleh rendahnya kadar estrogen yang memberikan efek protektif terhadap sel kanker. ${ }^{11}$ Estrogen berperan untuk menekan insulin like growth factor (IGF-1) dan asam empedu sekunder yang memicu tumbuhnya sel kanker. Estrogen reseptor beta (ER $\beta)$ juga bertugas untuk menginduksi apoptosis pada sel kanker yang bersifat antiproliferatif di sel epitel kolon. ${ }^{11}$

Penelitian Sandouk dkk (2013) menyebutkan bahwa peran estrogen sebagai protektor terhadap sel kanker hanya terjadi pada tahap adenoma berukuran kecil ke adenoma berukuran besar. ${ }^{12}$ Sementara 
terjadinya kanker kolorektal tidak hanya terbatas pada tahap tersebut. Tahapan untuk menjadi kanker kolorektal bermula dari perubahan epitel yang normal, hiperprolifersi epitel dan aberrant cryptic foci, adenoma berukuran kecil, adenoma berukuran besar, sehingga menjadi kanker kolorektal. ${ }^{12} \mathrm{Hal}$ tersebutlah yang menyebabkan rendahnya kadar estrogen tidak menjadi penyebab utama bagi seorang laki-laki untuk terkena kanker kolorektal. Terdapat faktor risiko lainnya yang turut serta menyebabkan laki-laki untuk terkena kanker kolorektal, seperti riwayat kanker kolorektal pada keluarga, riwayat Inflammatory Bowel Disease (IBD) pada individu, atau pola gaya hidup yang buruk. ${ }^{3}$

Karakteristik pasien berdasarkan umur menunjukkan hasil bahwa kelompok umur terbanyak adalah kelompok umur kelompok umur 50 - 59 tahun dengan jumlah 89 orang $(29,3 \%)$ dan yang paling sedikit ditemukan pada kelompok umur $>70$ tahun sebanyak 20 orang $(6,6 \%)$. Hasil ini sama dengan penelitian Devi dkk di RSUP Sanglah Denpasar pada tahun 2015-2017 yaitu umur pasien yang dilakukan pemeriksaan histopatologi biopsi massa kolorektal terbanyak kelompok umur 50 - 59 tahun yaitu sebanyak 89 orang $(26,6 \%) .{ }^{9}$ Kejadian kanker kolorektal meningkat progresif sejak umur 40 tahun dan akan meningkat tajam pada umur 50 tahun. ${ }^{13} \mathrm{Hal}$ ini dibuktikan dengan $>90 \%$ kejadian kanker kolorektal merupakan seseorang dengan umur yang lebih dari 50 tahun. ${ }^{13}$ Tingginya angka kejadian kanker kolorektal pada usia muda tersebut disebabkan oleh pola gaya hidup yang buruk seperti diet rendah serat, kelebihan asupan lemak, merokok dan mengonsumsi alkohol. ${ }^{11}$

Karakteristik pasien berdasarkan suku menunjukkan hasil bahwa suku terbanyak yang dilakukan pemeriksaan histopatologi biopsi massa kolorektal adalah suku Melayu yaitu sebanyak 54 orang (17,8\%). Hasil penelitian lain yaitu penelitian Pandiangan di RSUP H. Adam Malik Medan pada tahun 2016 - 2018 menunjukkan bahwa penderita kanker kolorektal terbanyak adalah suku Batak yaitu sebanyak 129 orang $(52,2 \%){ }^{14}$ Pemeriksaan biopsi massa kolorektal yang didominasi oleh suku Melayu ini bukan berarti menunjukkan bahwa suku tersebut berisiko untuk memiliki massa kolorektal. Hal tersebut hanya menujukkan bahwa jumlah pasien yang datang berobat pada RSUD Arifin Achmad Provinsi Riau pada umumnya adalah suku Melayu dan suku mayoritas di Provinsi Riau adalah suku Melayu.

Suku lain yang dapat berisiko untuk terkena kanker kolorektal adalah suku Sunda. Suku Sunda memiliki kebiasaan memakan lalapan yang dipercaya mampu meningkatkan kehalusan dan kelembutan kulit mereka. Lalapan merupakan sayur-sayuran yang mengandung $\beta$-karoten yang berperan dalam mengatur kualitas kulit. Lalapan yang tidak dicuci sebelum dikonsumsi mengandung residu pestisida yang dapat mencetuskan terjadinya kanker kolorektal. Residu pestisida yang terdapat di dalam sayur-sayuran dapat menimbulkan efek secara tidak langsung terhadap manusia. Residu pestisida yang terbawa bersama makanan akan terakumulasi pada jaringan tubuh yang mengandung lemak. Akumulasi residu pestisida ini pada manusia dapat merusak fungsi hati, ginjal, sistem saraf, menurunkan kekebalan tubuh, menimbulkan cacat bawaan, alergi, dan kanker. ${ }^{15,16}$

Karakteristik pasien berdasarkan pekerjaan menunjukkan hasil bahwa pekerjaan terbanyak yang dilakukan pemeriksaan histopatologi biopsi massa kolorektal adalah Ibu Rumah Tangga (IRT) sebanyak 67 orang (22\%). Hasil penelitian ini sama dengan penelitian Pandiangan di RSUP H. Adam Malik Medan pada tahun 2016 - 2018 yang menunjukkan bahwa pekerjaan penderita kanker kolorektal terbanyak adalah Ibu Rumah Tangga (IRT) yaitu 67 orang (22\%). Pekerjaan seseorang berhubungan dengan aktivitas fisik yang dialaminya dalam kehidupan sehari-hari. Aktivitas fisik yang tinggi berhubungan dengan rendahnya angka kejadian kanker kolorektal. Aktivitas fisik akan meningkatkan angka metabolik dan ambilan oksigen maksimal. ${ }^{13}$ Dampak jangka panjang yang dihasilkan dengan beraktivitas fisik yang tinggi adalah meningkatkan efisiensi dan kapasitas metabolik tubuh serta menurunkan tekanan darah dan resistensi insulin. Selain itu, aktivitas fisik juga dapat meningkatkan motilitas usus. ${ }^{13}$ Kurangnya aktivitas fisik dan gaya hidup sedentary tanpa sadar sering dilakukan oleh pekerjaan seperti Ibu Rumah Tangga (IRT). ${ }^{17} \mathrm{Hal}$ ini akan meningkatkan angka kejadian obesitas yang juga merupakan salah satu faktor risiko terjadinya kanker kolorektal. ${ }^{13}$

Pekerjaan lain yang dapat berisiko untuk terkena kanker kolorektal adalah petani. Hal ini 
disebabkan karena paparan pestisida yang dialami oleh petani melalui inhalasi, saluran pencernaan, dan dermal.. ${ }^{18}$ Pestisida digunakan oleh petani untuk membasmi hama tanaman, meningkatkan mutu dan produktivitas hasil pertanian. Dampak jangka panjang dari paparan pestisida di antaranya adalah kanker, asma, parkinson, dan diabetes. Penelitian Lee et al (2010) menyebutkan bahwa terdapat 305 insiden kanker kolorektal pada petani yang didiagnosa selama masa studi 1993 - 2002 di Lowa dan Carolina Utara. Hasil ini sesuai dengan penelitian ini yang menunjukkan bahwa petani merupakan pekerjaan terbanyak kedua setelah Ibu Rumah Tangga (IRT) untuk mendapatkan massa kolorektal. ${ }^{16,19}$

\section{Diagnosis Klinik Pasien yang Dilakukan Pemeriksaan Histopatologi Biopsi Massa Kolorektal}

Hasil penelitian menunjukkan bahwa diagnosis klinik pasien yang dilakukan pemeriksaan histopatologi biopsi massa kolorektal paling banyak adalah tumor rektum yaitu sebanyak 222 kasus $(73,1 \%)$ dan yang paling sedikit adalah tumor kolon desendens yaitu sebanyak 4 kasus $(1,3 \%)$. Hasil ini sama dengan penelitian Devi dkk di RSUP Sanglah Denpasar pada tahun 2015-2017 yaitu diagnosis klinik pasien yang dilakukan pemeriksaan histopatologi biopsi massa kolorektal terbanyak adalah tumor rektum yaitu sebanyak 187 kasus $(60,7 \%)^{9}$

Kejadian massa kolorektal terbanyak pada lokasi rektum diakibatkan oleh mukosa rektum yang memiliki risiko 4 kali lipat lebih banyak untuk mengalami transformasi keganasan dibandingkan dengan mukosa kolon. ${ }^{20}$ Sepertiga bagian proksimal rektum dilindungi oleh peritoneum, sementara bagian tengah dan distal rektum kekurangan lapisan pelindung luar yaitu serosa sehingga tumor mudah untuk menginvasi dan menyebar secara lokal. ${ }^{21,22}$

\section{Gambaran Histopatologi Biopsi Massa Kolorektal}

Hasil penelitian ini menunjukkan bahwa gambaran hasil pemeriksaan histopatologi biopsi massa kolorektal yang paling banyak adalah neoplasma ganas sebanyak 219 spesimen (72\%) dengan adenokarsinoma yang berjumlah
197 spesimen $(64,8 \%)$ sebagai gambaran mayoritasnya. Hasil penelitian ini juga menunjukkan bahwa dari seluruh hasil pemeriksaan histopatologi biopsi massa kolorektal neoplasma jinak paling banyak yaitu adenoma sebanyak 3 spesimen (1\%) dan non-neoplasma paling banyak adalah kolitis kronik non spesifik sebanyak 58 spesimen $(19,1 \%)$. Hasil penelitian ini sesuai dengan penelitian yang dilakukan oleh penelitian Devi dkk di RSUP Sanglah Denpasar pada tahun 2015-2017 yaitu gambaran hasil pemeriksaan histopatologi biopsi massa kolorektal yang paling banyak adalah neoplasma ganas dengan adenokarsinoma sebagai gambaran mayoritasnya sejumlah 217 spesimen $(70,45 \%)$ kemudian diikuti oleh gambaran neoplasma jinak yaitu adenoma sebanyak 74 spesimen $(24,03 \%) .{ }^{9}$ Namun, penelitian tersebut memiliki gambaran histopatologi non-neoplasma terbanyak yang berbeda yaitu polip hiperplastik sebanyak 6 spesimen $(1,95 \%) .{ }^{9}$ Hal ini disebabkan karena pemeriksaan histopatologi biopsi massa kolorektal yang dilakukan pada penelitian tersebut tidak mencantumkan kolitis kronik non spesifik sebagai salah satu variabel penelitiannya.

Penentuan jenis histopatologi massa kolorektal sangat penting untuk menentukan terapi dan prognosis. ${ }^{23}$ Polip kolon memiliki prognosis baik dan dapat diterapi dengan eksisi lokal atau polipektomi sederhana. ${ }^{1,3}$ Inflammatory Bowel Disease (IBD) seperti Crohn's Disease, kolitis ulseratif, dan kolitis kronik non spesifik dapat diterapi dengan menggunakan kortikosteroid, aminosalisilat, agen-agen imunosupresif seperti azathioprine, antibiotik seperti metronidazole, dan antibiotik spektrum luas dalam beberapa kasus. ${ }^{24}$ Pasien yang menderita Inflammatory Bowel Disease (IBD) selama lebih dari 8-10 tahun akan meningkatkan risiko untuk terjadinya displasia epitel kolon dan adenokarsinoma. ${ }^{1}$ Adenoma merupakan polip neoplastik yang memiliki potensi berkembang menjadi karsinoma terutama jenis sessile serrated adenoma. ${ }^{1}$ Polipektomi harus dilakukan apabila adenoma ditemukan untuk mencegah perkembangan menjadi karsinoma. ${ }^{3}$

Kanker kolorektal pada stadium dini dapat dilakukan terapi bedah berupa reseksi dengan tujuan kuratif. Kanker pada stadium lanjut dapat dilakukan kemoterapi sebagai pilihan pertama dengan tujuan 
paliatif. Terapi kanker rektum dapat dilakukan radioterapi sebagai salah satu modalitas utama dalam penatalaksanaannya. Terapi biologis (targeted therappy) dengan antibodi monoklonal saat ini telah berkembang pesat dan dapat diberikan dalam berbagai situas klinis yaitu berupa obat tunggal atau dapat dikombinasikan dengan modalitas terapi kanker kolorektal lainnya. ${ }^{3}$

Mucinous adenocarcinoma memiliki prognosis yang lebih buruk di antara jenis adenokarsinoma lainnya. ${ }^{25} \mathrm{Hal}$ ini disebabkan karena mucinous adenocarcinoma merupakan jenis adenokarsinoma yang berdiferensiasi buruk, dapat menginvasi ke dalam limfosit, dan banyak dari Micro-Satelite Instability (MSI-H) berasal dari jenis histopatologi ini. ${ }^{2,26}$ Signet ring cell carcinoma juga merupakan jenis kanker kolorektal yang memiliki prognosis yang buruk, namun termasuk ke dalam jenis kanker yang jarang terjadi yaitu dengan insiden kasus kurang dari $1 \%{ }^{27} \mathrm{Hal}$ ini disebabkan oleh gejala yang timbul terlambat dan biasanya didiagnosa saat kanker sudah berada pada stadium lanjut. ${ }^{27}$ Kanker ini juga berdiferensiasi buruk dan biasa terjadi pada usia dewasa muda. ${ }^{2,27}$

\section{Gambaran Histopatologi Biopsi Massa Kolorektal Berdasarkan Diagnosis Klinik}

Hasil penelitian ini menunjukkan bahwa tumor rektum merupakan diagnosis klinik yang paling banyak ditemukan dengan gambaran histopatologi non-neoplasma sebanyak 51 orang $(16,9 \%)$, neoplasma jinak sebanyak 3 orang $(1 \%)$ dan neoplasma ganas sebanyak 168 orang $(55,2 \%)$. Gambaran histopatologi berupa neoplasma ganas paling banyak terdapat di daerah rektum. Hasil penelitian ini sesuai dengan penelitian Hamdi dkk (2015) bahwa lokasi karsinoma kolorektal di Laboratorium Patologi Anatomi Fakultas Kedokteran Universitas Andalas Periode Januari 2009 sampai Desember 2011 terbanyak yaitu di rektum dengan jumlah 131 orang $(50,4 \%) .{ }^{5}$ Penyebab kanker lebih sering terjadi di daerah rektum adalah karena mukosa rektum yang memiliki risiko 4 kali lipat lebih banyak untuk mengalami transformasi keganasan dibandingkan dengan mukosa kolon. ${ }^{20}$ Daerah rektum lebih sering terpapar dengan feses secara tidak langsung sehingga mengakibatkan perubahan lingkungan dan mempengaruhi tingkat kerentanan rektum terhadap proses karsinogenik yang terjadi. ${ }^{21}$ Selain itu, rekurensi lokal juga lebih sering terjadi pada kanker rektum daripada kanker kolon. ${ }^{28}$

Tumor kolon desendens merupakan diagnosis klinik yang paling sedikit ditemukan dengan gambaran histopatologi non-neoplasma sebanyak 1 orang $(0,3 \%)$, neoplasma jinak sebanyak 1 orang $(0,3 \%)$, dan neoplasma ganas sebanyak 2 orang $(0,7 \%)$. Gambaran histopatologi berupa neoplasma ganas paling sedikit ditemukan di daerah kolon desendens. Hasil penelitian ini sesuai dengan teori bahwa letak keganasan kolorektal terendah yaitu pada kolon desendens sebanyak 5\%. ${ }^{29}$ Lokasi karsinoma kolorektal paling sedikit menurut Hamdi dkk adalah sekum sebanyak 2 orang $(0,7 \%) .{ }^{5}$ Hasil tersebut berbeda dengan hasil penelitian ini, tetapi jumlah frekuensi dan persentase pada hasil penelitian ini tidak jauh berbeda.

Penelitian ini hanya mengambil sampel penelitian berupa spesimen yang berasal dari biopsi massa kolorektal kemudian dilakukan pemeriksaan histopatologi di Instalasi Patologi Anatomi RSUD Arifin Achmad Provinsi Riau Periode Januari 2015 Desember 2019, sehingga inilah kebaruan penelitian ini dibandingkan peneltian lainnya.

\section{KESIMPULAN}

Penelitian ini mendapatkan 304 kasus pemeriksaan histopatologi biopsi massa kolorektal di RSUD Arifin Achmad Provinsi Riau Periode Januari 2015 - Desember 2019. Profil klinikopatologik kasus terdiri dari laki-laki lebih banyak dari perempuan (55,6\%:44,4\%). Jumlah kasus tertinggi pada kelompok umur 50-59 tahun. Suku Melayu merupakan suku yang terbanyak. Pekerjaan yang tertinggi adalah Ibu Rumah Tangga. Tumor rektum merupakan diagnosis klinik yang tersering. Gambaran histopatologi terdiri dari kasus nonneoplasma dengan gambaran terbanyak adalah kolitis kronik non spesifik, neoplasma jinak dengan gambaran terbanyak adalah adenoma dan neoplasma ganas dengan gambaran terbanyak adalah adenokarsinoma. Sebagian besar kasus adalah neoplasma ganas, sehingga dapat disimpulkan bahwa biopsi dan pemeriksaan histopatologi sangat membantu dalam penegakan diagnosis kanker kolorektal sejak dini. 


\section{DAFTAR PUSTAKA}

1. Aster KA. Robbins basic pathology. 9th ed. Philadelphia: Saunders Elsevier; 2015.

2. Hamilton SR, Aaltonen LA, editors. Pathology and genetics of tumours of the digestive system. In: World Health Organization Classification of Tumours. Lyon: IARC Press; 2000. p. 318-22.

3. Komite Penanggulangan Kanker Nasional. Panduan penatalaksanaan kanker kolorektal. Dalam: Panduan penatalaksanaan kanker kolorektal. Kemenkes RI; 2015. p. 76.

4. Ferlay J, Soerjomataram I, Dikshit R, Eser S, Mathers C, Rebelo M, et al. Cancer incidence and mortality worldwide: Sources, methods and major patterns in GLOBOCAN 2012. Int J Cancer. 2015;136(5):E359-86.

5. Hamdi M, Zahari A, Aswiyanti. Profil karsinoma kolorektal di laboratorium patologi anatomi Fakultas Kedokteran Universitas Andalas periode Januari 2009 sampai Desember 2011. J Kesehat Andalas. 2015;4(2):398-403.

6. Aspitriani. Peranan pemeriksaan patologi anatomi dalam deteksi dini dan penanggulangan kanker [Internet]. Kemenkes RI. 2019 [cited 2020 Jun 28]. Available from: http://yankes.kemkes.go.id/ read-peranan-pemeriksaan-patologi-anatomidalam-deteksi-dini-dan-penanggulangankanker--6557.html

7. Sayuti M, Nouva. Kanker kolorektal. AVERROUS J Kedokt dan Kesehat Malikussaleh. 2019;5(2):76-88.

8. Zahari A. Deteksi dini, diagnosa, dan penatalaksaan kanker kolon dan rektum. Majalah kedokteran ANDALAS, FK UNAND. 2011;98121.

9. Devi PJC, Sriwidyani NP, Ekawati NP. Karakteristik klinikopatologi pasien tumor kolorektal yang menjalani biopsi kolonoskopi di RSUP Sanglah Denpasar Tahun 2015-2017. J Med Udayana. 2020;9(2):56-60.

10. Fuadi I, Makmun D, Krisnuhoni E, Abdullah M. Tingkat kesesuaian pemeriksaan histopatologi biopsi perkolonoskopi dibandingkan pemeriksaan histopatologi pada saat pembedahan pada pasien dengan tumor kolon di Pusat Endoskopi dan
Saluran Cerna RSCM Tahun 2006-2015. J Penyakit Dalam Indones. 2017;4(3):146-50.

11.Hapsari PK, Murbawani EA. Hubungan asupan serat, lemak dan kalsium dengan kejadian karsinoma kolorektal di Semarang. J Nutr Coll. 2016;5(4):461-8.

12.Sandouk F, Jerf F Al, Al-Halabi MHDB. Precancerous lesion in colorectal cancer. Gastroenterol Res Pract. 2013;2013:1-11.

13. Khosama Y. Faktor risiko kanker kolorektal. Cermin Dunia Kedokt. 2015;42(11):829-32.

14.Pandiangan MT. 2019. Karakteristik penderita kanker kolorektal yang dirawat inap di RSUP H. Adam Malik Medan Tahun 2016-2018. Skripsi. Fakultas Kesehatan Masyarakat. Universitas Sumatera Utara, Medan.

15.Amrinanto AH, Hardinsyah, Palupi E. Tingkat kebiasaan makan lalapan masyarakat Sunda, hubungannya dengan asupan dan kadar $\beta$-karoten, serta persepsi kualitas kulit. Institut Pertanian Bogor; 2019.

16.Akbar F. 2013. Analisis risiko kesehatan pajanan residu klorpirifos dalam bayam (Amaranthus sp.) pada masyarakat di Kabupaten Gowa. Tesis. Fakultas Kesehatan Masyarakat. Universitas Hasanuddin Makassar, Makassar.

17.Fuadianti TF. 2018. Hubungan antara gaya hidup sedentary dan stres dengan obesitas pada ibu rumah tangga. Fakultas Psikologi, Universitas Muhammadiyah Surakarta, Surakarta.

18. Maria G. Catur Yuantari, Widianarko B, Sunoko HR. Analisis risiko pajanan pestisida terhadap kesehatan petani. J Kesehat Masy Andalas. 2015;10(2):239-45.

19.Putri ARA. Hubungan paparan pestisida dan kadar kolinesterase dengan hipertensi pada petani di Kecamatan Juhar Kabupaten Karo tahun 2019 [Internet]. Repositori Institusi USU. Universitas Sumatera Utara; 2019. Available from: http:// repositori.usu.ac.id/handle/123456789/17272

20.Paschke S, Jafarov S, Staib L, Kreuser ED, Maulbecker-Armstrong C, Roitman M, et al. Are colon and rectal cancer two different tumor entities? A proposal to abandon the term colorectal cancer. Int J Mol Sci. 2018;19(9):1-24. 
21.Fazeli MS, Keramati MR. Rectal cancer: A review. Med J Islam Repub Iran. 2015;29:1-23.

22.Zalewski S. How colon and rectal cancer differ [Internet]. Michigan Health. 2019 [cited 2021 Feb 15]. Available from: https://healthblog. uofmhealth.org/cancer-care/how-colon-andrectal-cancer-differ

23. Manxhuka-Kerliu S, Telaku S, Ahmetaj H, Baruti A, Loxha S, Kerliu A. Colorectal cancer: prognostic values. Bosn J Basic Med Sci. 2009;9(1):19-24.

24.Pithadia AB, Jain S. Treatment of inflammatory bowel disease (IBD). Pharmacol Reports. 2011;63(3):629-42.

25.Park JS, Huh JW, Park YA, Cho YB, Yun SH, Kim HC, et al. Prognostic comparison between mucinous and nonmucinous adenocarcinoma in Colorectal Cancer. Med (United States). 2015;94(15):1-6.
26.Catalano V, Loupakis F, Graziano F, Bisonni R, Torresi U, Vincenzi B, et al. Prognosis of mucinous histology for patients with radically resected Stage II and III Colon cancer. Ann Oncol [Internet]. 2012;23(1):135-41. Available from: https://doi.org/10.1093/annonc/mdr062

27.Belli S, Aytac HO, Karagulle E, Yabanoglu H, Kayaselcuk F, Yildirim S. Outcomes of surgical treatment of primary signet ring cell carcinoma of the colon and rectum: 22 cases Reviewed with Literature. Int Surg. 2014;99(6):691-8.

28.Pratama KP, Adrianto AA. Faktor-faktor yang mempengaruhi kejadian kanker kolorektal stadium III Di RSUP Dr Kariadi Semarang. J Kedokt Diponegoro. 2019;8(2):768-84.

29.Sjamsuhidajat R, Jong $\mathrm{W}$ de, editors. Usus halus, apendiks, kolon, dan anorektum. In: Buku Ajar Ilmu Bedah. 2nd ed. Jakarta: EGC; 2005. p. 658. 